\title{
A CASE OF CARCINOMA OF THE BRONCHUS ASSOCIATED WITH HORMONAL ABNORMALITIES
}

\author{
J. BRANSON, M.B., B.S., M.R.C.P., \\ Senior House Officer in Medicine
}

S. OleEsky, M.Sc., M.B.(Manch.)., F.R.C.P. Consultant Physician

\author{
L. A. Turnberg, M.B., Oh.B., M.R.C.P. \\ Senior Registrar in Medicine
}

Manchester Royal Infirmary, Oxford Road, Manchester 13

IT IS well recognised that hormonal disorders may occur in association with carcinoma of the bronchus. Changes suggesting an excess secretion of antidiuretic hormone, adreno-corticotrophic hormone or a parathormone-like substance are well described (Riggs and Sprague, 1961; Ross, 1963; Plimpton and Gellhorn, 1956). In the majority of reported instances the abnormality has been an isolated one and it is suggested that the tumour itself elaborates the polypeptide which has hormonal actions (Ross, 1956; Jarett, Lacy and Kipnis, 1964; Goldberg, Tashjian, Order and Dammin, 1964).

The accurence of a pattient in whom there is evidence of two such hormonal abnormalities is of interest and stresses the apparent multipotential of primitive neoplastic cells.

\section{Case report}

P.F., a 57 year old grocer, gave a 12-month's history of gradually deteriorating mental health. He was becoming increasingly forgetful and during the two months prior to admission, was often confused. He was unable to concentrate, could not calculate customers' bills correctly and was becoming slow and apathetic. The symptoms were severe enough to prevent his working during the two weeks before admission. His appetite was good and he had not lost weight. He smoked ten cigarettes per day and had a cough productive of mucoid sputum, but little dyspnoea on effort. Three years before the present admission he had been found to have thyrotoxicosis and given two therapeutic doses of radio-iodine.

On examination he appeared cheerful and euphoric, complaining of few symptoms. He was well orientated, but spoke slowly and with a deep gruff voice. His skin was coarse and pigmented and his eyebrows were thin. There was slight exophthalmos but no goitre. He had bilateral Dupuytren's contractures. The cardiovascular system was normal, BP 150/90 $\mathrm{mm}$. Hg. and there was no oedema. There were generalised rhonchi in both lung fields but no localised abnormalities. The liver, considerably enlarged to the umbilicus, was hard and irregular, but the spleen was impalpable. The central nervous system was normal and in particular, the tendon reflexes were normal and showed a normal relaxation.

Routine investigation showed:- Chest X-rayold calcified tuberculosis foci found at the apices and an abnormal shadow in the right lower lobe suggestive of a bronchial neoplasm. Cytological examination of the sputum revealed many malignant cells. X-ray of the lumbar spine showed wedging of the bodies of L4 and 5 suggesting secondary deposits. There was a leucoerythroblastic anaemia. $\mathrm{Hb}, 11.1 \mathrm{~g} / 100$ ml., MCHC $31 \%$, WBC $11,800 /$ cu.mm., $6.5 \%$ myelocytes and 2 nucleated red cells per 100 white cells. Investigation of liver function showed a normal serum albumin, globulin, bilirubin and thymol turbidity, but the alkaline phosphatase was $22 \mathrm{~K}$.A. units/ $100 \mathrm{ml}$. Prothrombin time was 14.5 seconds (normal 11 seconds). The serum protein bound iodine was $1.2 \mu \mathrm{g} / 100 \mathrm{ml}$., and serum cholesterol $230 \mathrm{mg} . / 100 \mathrm{ml}$. ECG was normal and did not show the changes associated with myxoedema. Serum calcium was 9.0 , inorganic phosphorous $1.6 \mathrm{mg} . / 100 \mathrm{ml}$.

More detailed investigation was carried out: Serum electrolyte estimations were made with the EEL Flame photometer. 17 keto- and ketogenis. steroid estimations were made by the method of Norymberski, Stubbs and West (1953). Plasma cortisol was measured by the method of Mattingly (1962). Urine osmolalities were measured with the "Fiske" osmometer.

On a normal ward diet the serum sodium varied between 119 and $125 \mathrm{mEq} / \mathrm{l}$., serum potassium between 3.9 and $4.5 \mathrm{mEq} / 1$., serum chloride between 74 and $76 \mathrm{mEq} / \mathrm{l}$., and the blood urea between 19 and $21 \mathrm{mg} / 100 \mathrm{ml}$ (see Fig. 1). Despite the low serum sodium the urinary sodium excretion was not reduced and varied between 46 and $120 \mathrm{mEq} /$ day. Potassium excretion ranged between 20 and $60 \mathrm{mEq} / \mathrm{day}$. Urine amino-acid chromatogram was normal. Urine osmolality was high on both occasions it was measured, 670 and $580 \mathrm{mOsmol} / \mathrm{Kg}$. Given a one-litre waterload he excreted only $16 \%$ of this in 4 hours, with a maximal flow rate of $1.2 \mathrm{ml} /$ minute. There was no fall in urine osmolality, the resting value was $698 \mathrm{mOsmol} / \mathrm{Kg}$., and during the 4-hour period after water ingestion the minimum value was 582 $\mathrm{mOsmol} / \mathrm{Kg}$., and the maximum $700 \mathrm{mOsmol} / \mathrm{Kg}$. Plasma cortisol was $42 \mu \mathrm{g} / 100 \mathrm{ml}$., at 9.30 a.m., our normal maximum being $25 \mu \mathrm{g} / 100 \mathrm{ml}$. Control daily ketosteroid excretion varied between 2.0 and 7.5 mg. and the ketogenic steroid excretion between 20.5 and $48.5 \mathrm{mg}$. Dexamethasone, in a dose of $8 \mathrm{mg} /$ day for three days, suppressed the ketogenic steroid outburst (see Table 1). Following this he was given thyroxin in a dose of $0.1 \mathrm{mg} /$ day for five days and then $0.2 \mathrm{mg} / \mathrm{day}$, but there was no change in his clinical condition, serum electrolyte concentration or urine sodium excretion. Finally, when still on thyroxin, treatment with $9 \alpha$-fludrocortisone $4 \mathrm{mg} /$ day produced a sharp rise in serum sodium 
TABLE 1

\begin{tabular}{|c|c|c|c|c|c|c|c|c|c|}
\hline Date & 21.6 & 24.6 & 29.6 & 30.6 & 1.7 & 3.7 & 4.7 & 5.7 & 8.7 \\
\hline Dexamethasone (mg) & - & - & 8 & 8 & 8 & - & - & - & - \\
\hline 17-Ketogenic steroid ( $\mathrm{mg} / 24$ hours) & 48.5 & 32.5 & 14.5 & 17.5 & 16.0 & 33.0 & 41.5 & 20.5 & 35.5 \\
\hline Ketosteroid (mg/24 hours) & 7.5 & 4.5 & 3.5 & 2.5 & 2.0 & 2.5 & 4.5 & 2.5 & 4.5 \\
\hline
\end{tabular}

within two days to $138 \mathrm{mEq} / 1$, in chloride to 88 $\mathrm{mEq} / 1$. The urine sodium excretion fell concurrently.

Further progress:- Although the patient's serum electrolytes improved, his clinical condition deteriorated. His liver grew rapidly in size and he became progressively anaemic. He lapsed into a coma and died one month after admission. Permission for post-mortem was refused.

\section{Discussion}

The low sodium state occurring in patients with carcinoma of the bronchus is thought to be due to the inappropriate secretion of antidiuretic hormone causing a dilution of serum electrolytes (Schwartz, Bennett, Curelop and Bartter, 1957). The resulting expansion of extracellular volume may reduce the secretion of

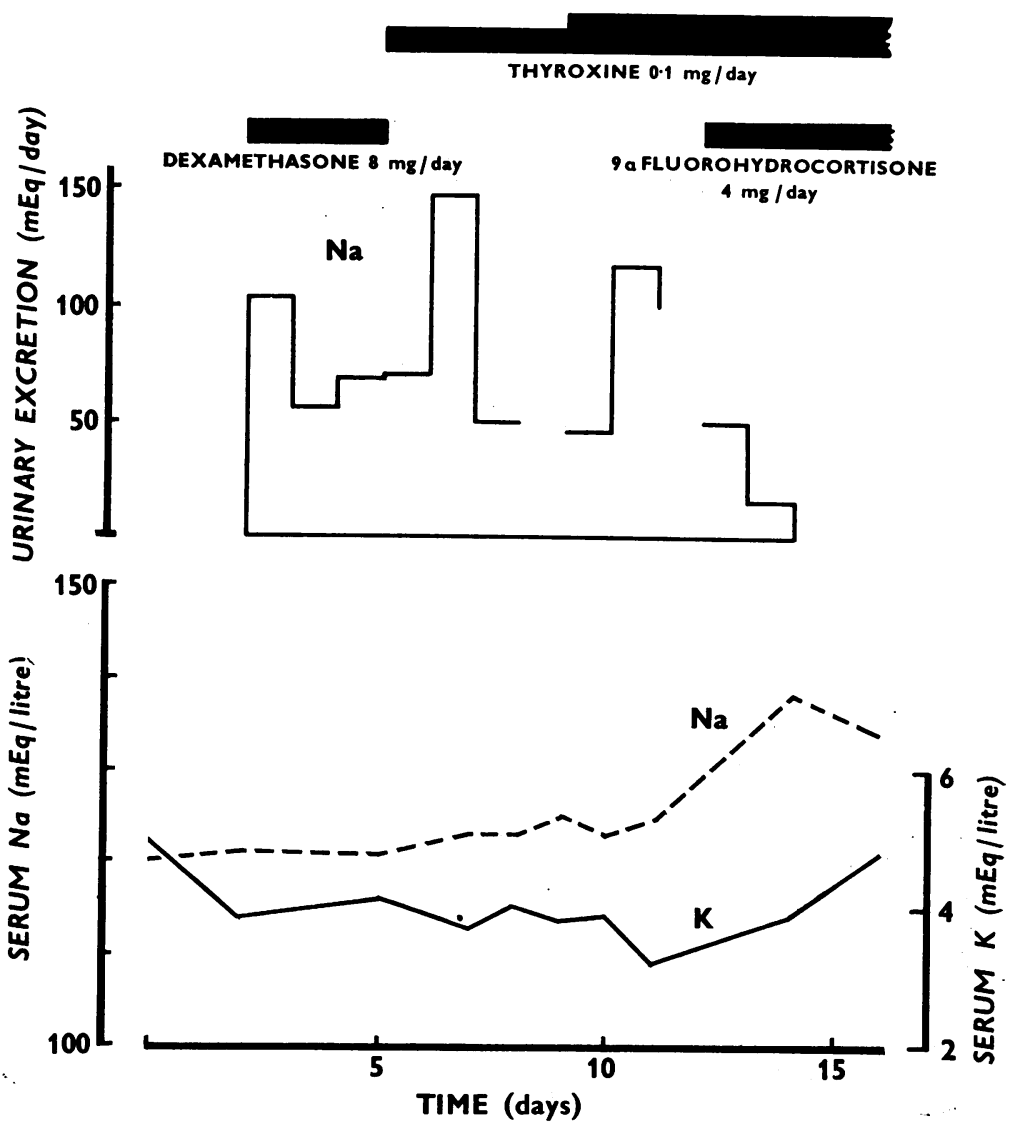


aldosterone, causing a urinary loss of inappropriate amounts of sodium because of a renal tubular defect. Ross (1963) describes well the two causes of hyponatraemia, dilution and depletion, occurring in patients with carcinoma of the bronchus. In this patient the low serum chloride and urea concentrations, the low haematocrit and absence of clinical signs of hypovolaemia suggest that the hyponatraemia resulted mainly from dilution. The continuing excessive renal sodium loss in the face of a low serum level suggests some depletion too, this being probably due to an impaired aldosterone secretion. There was no amino-aciduria or glyoosuria and thus no evidence of a tubular defect for reabsorption of these substances.

Administration of relatively large doses of $9 \alpha$-fludrocortisone is thought to suppress the release of anti-diuretic hormone, as well as causing retention of sodium by the renal tubules in those patients with a normal proximal tubular function (Ross, 1963). This causes an immediate rise in serum sodium and chloride and a concomitant fall in urinary excretion, as was seen in this patient.

It is uncertain how the iatrogenic hypothyroidism affected the electrolyte changes in this patient. There have been reports of low serum sodium values in myxoedema (see Goldberg and Reivich (1962) for review) but usually such patients have severe disease and ofiten have impending coma and death. Our patient's hypothyroidism was mild with a normal cholesterol, ECG and tendon reflexes, although he had the facies, voice and reduced serum protein-bound iodine. Primary hypothyroidism may impair the ability to excrete a water load but usually water excretion is normal or only slightly reduced (Oleesky, 1955). A low serum sodium may impair a water diuresis (Garrod and Burston, 1952; Oleesky, 1953), and this may have been a factor in this patient's defective walter excretion. Thyroxin was given without influencing the serum or urine electrolytes, suggesting that the hypothyroidism contributed little to the hyponatraemia and excessive urinary sodium excretion.

Hyper-adrenocorticalism occurring with neoplasms of the bronchus is thought to be due to secretion of an ACTH-like substance by the tumour (Jarett, Lacey and Kipnis, 1964). Two aspects in this patient are unusual and worthy of comment. Firstly, the serum potassium was normal, whereas similar patients usually have fairly severe hypokalaemia (Bagshawe, 1960). This patient's normal potassium may be due to reduction of aldosterone secretion consequent upon the hypervolaemia. It is noted, however, that the similar case of Daly, Nelson and Ross (1963) with a dual endocrine disorder, had a low serum potassium despite the hypervolaemia. The other unusual feature is the apparent suppression of the tumour by dexamethasone. This is an unexpected phenomenon in what is considered to be a state of autonomous secretion of ACTH by the tumour. Suppression suggests ability to $\underset{\nabla}{ }$ respond via a feed-back mechanism. Although $\_$ this is unexplained, it has been noted before $C$ (Freidman, Ross and Marshall-Jones, 1965)

With maturation, normal cells become specialised and also limited in their ability to produce a variety of proteins. However, it appears that the relatively undifferentiated cells of an anaplastic carcinoma or sarcoma are capable of a much $\stackrel{2}{2}$ wider expression. It is likely that these cells may produce complex polypeptides of different types, some of which exert hormonal actions. The present $\vec{\circ}$ patient and one other previously described (Daly, $\overrightarrow{ }$ Nelson and Ross, 1963) showed this potential $\omega$ to a marked degree by producing two active polypeptides.

\section{Summary}

A patient with carcinoma of the bronchus was : found to have hyponatraemia as well as an increased output of adrenal cortico-steroids, but $\rightarrow$ without the clinical picture of Cushing's syndrome. $\infty$ The serum sodium concentration rose with the 은 administration of $9 \alpha$-fludrocortisone. The in- creased output of 17-ketogenic steroid was sup- $D$ pressed by dexamethasone.

\section{REFERENCES}

Bagshawe, K. D. (1960): Hypokalaemia, Carcinong ce and Cushing's Syndrome, Lancet, ii, 284.

Daly, J. J., Nelson, M. A., and Ross, D. P. (1963) Hyponatraemia with Carcinoma of the Bronchus, Post grad. med. J., 39, 158.

Freidman, M., Ross, E. J., and Marshall-Jones, P. (1965): Hormonal Changes in Carcinoma of the Bronchus, quoted by Ross, E. J., in "Symposium $\mathbb{D}$ on Advanced Medicine" p. 371. London: Pitman.

GARroD, O., and Burston, R. A. (1952): The $\overrightarrow{\overrightarrow{0}}$ Diuretic Response to Ingested Water in Addison's 3 Disease and Pan-hypopituitarism and the Effect of Cortisone Thereon, Clin. Sci., 11, 113.

GoldberG, M., and Reivich, M. (1962): Studies on the Mechanism of Hyponatraemia and impaired Water Excretion in Myxoedema, Ann. intern. Med., 56, 120 .

Goldberg, M. F., Tashuian, A. H., Order, E. E., and DAMMIN, G. J. (1964): Renal Adenocarcinoma Containing a Parathyroid Hormone-like Substance and Associated with Marked Hypercalcemia, Amer. J. Med., 36, 805 .

JARETT, L., LACY, P. E., and KIPNIS, D. M. (1964): Characterization by Immunofluorescence of an ACTH-like Substance in Non-pituitary Tumours from Patients with Hyperadrenocortism, J. clin. O Endocr., 24, 543.

MatTingly, D. (1962): A Simple Fluorimetric N Method for the Estimation of Free 11-hydroxy- N corticoids in Human Plasma, J. clin. Path., 15, 374.

Norymberski, J. K., StubbS, R. D., and WeSt, H. F. (1953): Assessment of Adrenocortical Activity bye Assay of 17-ketogenic Steroids in Urine, Lancet, i, $\stackrel{\mathbb{Q}}{\mathbb{Q}}$ 1276.

Oleesky, S. (1953): A Specific Water Diuresis Test for Adrenocortical Insufficiency, Lancet, i, 789.

OleEsKY, S. (1955): Water Diuresis in Primary Myxoedema, Lancet, i, 256. 政

\section{.}


Plimpton, C. H., and GellhorN, A. (1956): Hypercalcemia in Malignant Disease without Evidence of Bone Destruction, Amer. J. Med., 21, 750.

RiggS, B. L., and Sprague, R. G. (1961): Association of Cushing's Syndrome and Neoplastic Disease, Arch. intern. med., 108, 841.

Ross, E. J. (1965): Hormonal Syndromes in Carcinoma of the Bronchus in "Symposium on Advanced Medicine” p. 377. London: Pitman.
Ross, E. J. (1963): Hyponatraemic Syndromes Associated with Carcinoma of the Bronchus, Quart. J. Med., 32, 297.

Schwartz, W. B., Bennett, W., Curelop, S., and BARTTER, F. C. (1957): A Syndrome of Renal Sodium Loss and Hyponatremia Probably Resulting from Inappropriate Secretion of Antidiuretic Hormone, Amer. J. Med., 23, 529.

\title{
THROMBOCYTOPENIC PURPURA WITH BRONCHIAL CARCINOMA
}

\author{
J. B. Cocking, M.A. M.B., B.Chir. \\ Medical Registrar, Royal Infirmary, Sheffield, 6
}

No CASE appears to have been recorded of thrombocytopenia in association with non-metastasising carcinoma, in which the bone marrow megakaryocytes were numerically normal or increased.

The occurrence of leucoerythroblastic anaemia from infiltration of bone marrow with carcinoma cells is well documented (Vaughan, 1936): thrombocytopenia may be a feature (West, Ley and Pearson, 1955), and occasionally may occur alone (Willis, 1942); the marrow megakaryocytes in such cases are usually numerically reduced. There are a few reports in which bone marrow metastases are found with normal numbers of megakaryocytes and thrombocytopenia (Stefanini, 1955; Christenson, Ultmann and Mohos, 1956).

\section{Case Report}

A female receptionist, aged 62 years, was admitted to the Royal Infirmary, Sheffield, on the 3rd March, 1965. She had developed a cough with haemoptysis on the 24th February, followed by rapidly progressive purpura, with bleeding into the substance of the tongue and into the lower gastro-intestinal tract.

In the three months prior to admission she had lost $10 \mathrm{~kg}$. in weight; this could be partly attributed to loss of dependent oedema for which she had received oral diuretics at home. Initially she had been treated for "a few weeks" with bendrofluazide 5 mg. b.d.; this was changed to frusemide on the 18th January, starting with $40 \mathrm{mg}$. daily and increased at intervals to b.d. then t.d.s. Quinidine $200 \mathrm{mg}$. daily was added at the beginning of February for palpitation.

All drugs were stopped on the day she started to bleed and develop purpura, but as no improvement ensued, she was admitted to hospital eight days later.

Further questioning elicited that she had smoked some twenty cigarettes a day for twenty years.

On examination she was afebrile; there were generalised purpuric lesions in the skin and mucous membranes of the mouth; the tongue was swollen, with ecchymoses on the inferior surface; signs at the base of the left lung were consistent with a pleural effusion. No lymphadenopathy was noted; pulse rate $120 / \mathrm{min}$., regular; $\mathrm{BP} 110 / 80 \mathrm{~mm}$. $\mathrm{Hg}$. Otherwise there were no relevant findings.

Investigations. Chest X-ray demonstrated a large left-sided pleural effusion tracking up the oblique fissure. No bony deposits were seen in dorsal spine, ribs, sternum or clavicles. Hb $45 \%(6.5 \mathrm{~g} / 100 \mathrm{ml}$.). WBC $13.000 / \mathrm{cu}$. mm., platelets less than 10,000 cu. mm., ESR (Westergren), $80 \mathrm{~mm} / \mathrm{hr}$.

Bone marrow-abnormalities noted were an in crease in the megakaryocytes which were of abnorma $\bar{\hbar}$ morphology, with gross maturation arrest; a pioture consistent with idiopathic thrombocytopenic purpura.

There was microscopic haematuria.

Group $\mathbf{O}$ Rh Positive, Direct Antiglobulin test negative. No red or white cell antibodies were detected.

Tests for complete and incomplete platelet anitibodies were negative. These were carried out using the patient's serum alone and also using it in the presence of pharmacological amounts of bendrofluazide, frusemide and quinidine.

No LE cells were seen. Antinuclear factors were not detected.

Urea, electrolytes, plasma proteins were within the normal range.

Treatment was with blood transfusion of packed cells and prednisolone $60 \mathrm{mg} /$ day. Within six days the platelet count had started to rise and on the 22nd March was 200,000/\%u. mm.; the purpura had resolved.

Pleural aspiration was performed when the platelet count was within normal limits; the fluid was blood stained and contained malignant cells. Signs of underlying consolidation in the left upper lobe could then be elicited.

Her condition slowly deteriorated and on the 11 th April she died; there was no recurrence of the purpura; platelet count four days before death was $300,000 /$ cu. $\mathrm{mm}$.

Necropsy revealed a right-sided pulmonary embolus, and a $6 \mathrm{~cm}$. diameter tumour in the left upper lobe extending into the hilum of the lung and invading the pericardium; microscopy showed it to be a bronchogénic carcinoma of mixed squamous and glandular pattern. No skeletal metastases were 